\title{
What does it Take to Succeed in Small Business in Pakistan? the Lessons for Emerging Entrepreneurs
}

\author{
Manzoor Ali Mirani and Syed Mir Muhammad Shah
}

\begin{abstract}
A lot has been written and researched worldwide to find out the characteristics of successful entrepreneurs and also reasons of success. Considering the general awareness about entrepreneurship and starting the new businesses, this study explores the reasons of successful business in Sukkur, Pakistan. The semi-structured interviews conducted from the businessmen running their business for the last three years revealed that the factors responsible for doing successful business in Sukkur were the motivation for business, good relations with suppliers in retail trade and with customers in services, consistency in business to overcome seasonal effects and understanding the environment for business very well to respond with suitable strategies.
\end{abstract}

Index Terms-Small business, success factors, sukkur, pakistan.

\section{INTRODUCTION}

The correlation between economic growth and entrepreneurship dates back to 1934 [1]. Since then the nations are focusing their efforts on enhancing the entrepreneurial activities to boost economic development. The study of available literature reveals that entrepreneurship and the creation of small businesses have been very instrumental for the developed and developing nations. [2] categorizes $90 \%$ of all the firms in any developing country as small and medium enterprises and he mentions that $90 \%$ of these SMEs are micro entrepreneurs. This refers to the importance of these small businesses for development and the employment creation. The contribution of small businesses in employment creation was $58 \%$ in USA [3]. The same trend has been in Europe in general also and particularly the studies in Estonia find the SMEs as the generators of employment and a positive factor in economic development [4], [5]. SMEs and micro entrepreneurs are very necessary for the economic movement of any country. This is supported by [6]. Their research finds positive relationship between entrepreneurial activities and the economic outcomes. The recent study by [7] also suggests that entrepreneurship is important for both predicting and explaining the economic performance of both developing and developed nations.

Pakistan being the developing nation strives for economic growth. Initially Pakistan government focused on development of large scale businesses and ignored the small business [8]. He further maintains that small businesses

Manuscript received March 15, 2012; revised April 26, 2012.

M. A. Mirani and S. M. M. Shah are with the Department of Business Administration Sukkur Institute of Business Administration Sukkur, Sind, Pakistan.(e-mail: manzoor@iba-suk.edu.pk; syedmir@iba-suk.edu.pk). emerged in Pakistan as informal sector. Therefore the development of this sector can not be attributed to government's formal policies in country. [9] reports following facts about SMEs in Pakistan:

"There are about 3.2 million enterprises in Pakistan, of which about 3 million (93 percent) are SMEs. SMEs spread across the economy with varying density: Most are in wholesale and retail trade and restaurants and hotels (53 percent), followed by other services (27 percent) and the manufacturing sector (20 percent)." The same report mentions that in Pakistan SMEs contribute more than 30 percent to the GDP and 25 percent to the country's total export earnings, and they employ close to 70 percent of the labor force in the manufacturing industry, services, and trade.

The above report indicates the importance and critical role of SMEs in Pakistan. Therefore SMEs needed the focus of policy makers and researchers in Pakistan. But the SMEs have grown in the country as an informal sector so for [8].

\section{LITRATURE REVIEW}

Small business has attracted many researchers to investigate different aspects like reasons or motivations for the entrepreneurs, the environment, and the characteristics of successful entrepreneurs and the reasons of failure for these businesses also to name few areas of research. Although it is very difficult to present single model or set of reasons for successful business but there is huge literature available to answer this question.

To answer the above phenomena, various interesting studies have been conducted. One comprehensive study was conducted by [10] which presented several reasons for success in small business like leadership characteristics of entrepreneur, motivation for entrepreneurs, good time management, operations management and the availability of able employees for the business.

A study by [11] mainly focused on the findings on demographic characteristics of entrepreneurs like their age, education, experience, planning abilities and to dealing with different parties like customers and employees of the firm. While [12] focused their research on organization's general and task environment in addition to characteristics of entrepreneur as found in earlier studies.

In a study in by [13] product quality and the commitment to it was given priority for business success and in addition to some four factors like marketing innovation, flexibility, relationships with suppliers and customer also emerged as success factors.

A more focused study on retail trade success factors by [14] mentions that the experience of entrepreneur and his 
knowledge of the retail market are very important for success.

Keeping in view the research studies on success factors in small business worldwide and the importance of SMEs in Pakistan, this study explores the factors of success in small business in Sukkur, Pakistan.

\section{Methodology}

Semi-structured interviews were conducted from 50 owners of small businesses in Sukkur. These small businesses included the retail and service business. The selected businesses were running for the last three years successfully because [15] defines that the ability to survive is the way to make a business successful. Looking into the literature available on success and failure studies and the factors responsible for it, it was very difficult to draw a common list for all markets and economies. Therefore it was decided to conduct semi-structure interviews to know the insights from the entrepreneurs themselves and then to develop a set of factors for the Sukkur area to make it simple and more generalizable. The collected data was compiled and analyzed for the new entrepreneurs.

\section{FIndings AND Discussion}

The detailed analysis of responses generated during interviews revealed various factors. To make these factors understandable similar factors were combined and general categories of variables were developed. The categories are;

\section{A. Characteristics of Entrepreneurs}

When asked about the motivation, the respondents preferred self-employment mainly because of unavailability of jobs in this area. While, family background was also a contributory factor for starting a new business.

The respondents categorized the ability to find out the opportunity as the important factor of success because they reported that many individuals only followed the trend of new business in market and ended in failure of that business. In entrepreneurship literature it is known as entrepreneurial alertness [16] and the creation of innovation [1]. The respondents rated the age; education and experience of doing business at lower level.

\section{B. Relationship Building}

When asked about relationship building in doing retail business, the respondents from retail trade agreed on developing good relations with suppliers to get timely deliveries and discounts, while the respondents from service business preferred the relations with customer to generate repeat sales. When inquired about the relations with employees, the respondents called it good behavior with employees instead of good relations.

\section{Persistence/Patience}

The respondents in general talked about the seasonal effects on business and reported that patience was very necessary to face this phenomenon. They reported that a new entrant into retail business usually did not consider this effect and face the failure. They need to be patient to wait for season and do business accordingly.

\section{Environment for Business}

When inquired about the role of general environment for success of business in Sukkur, the respondents interestingly considered the environment hostile for their business. Because the law and order situation in Pakistan was not favorable for doing business in Pakistan. They also criticized the behavior of government agencies for creating hurdles and also the lack of electricity and gas. They also talked about the economic conditions as a force against doing business. The businessmen who understand this environment very well can devise strategies to benefit from the environment. The competition from existing businesses was also a major contributory factor in determining the success of new business.

\section{CONCLUSION}

When findings of study are compared with the literature available on success factors of small business it is very difficult to generate the one for all solution. Even then the current findings have reasonable implication for the emerging entrepreneurs in Pakistan to consider the factors that can lead them to success and minimize the chances of their failure. The study concludes that the factors responsible for doing business in Sukkur are the motivation for business, good relations with suppliers in retail trade and with customers in services, persistence in business to overcome seasonal effects and understanding the environment for business very well to respond with suitable strategies.

The findings of the study are applicable to new entrepreneurs and the existing entrepreneurs in the small businesses in this region. The results help them analyze the business environment and devise the business strategies accordingly. The entrepreneurs in the region need to focus on innovative business opportunity instead of following the current trends of business. Relationships are another area to be focused by the entrepreneurs in small business particularly in services business. Persistence is another variable for success to avoid the troubles in business for small business. These entrepreneurs need to understand the business environment completely to be successful in the region.

\section{REFERENCES}

[1] J. A. Schumpter, The Theory of Economic Development: Harvard University Press, 1934.

[2] M. T. Schaper, "Distribution Pattern of small firms in developed economies: Is there an emergent global pattern?" International Journal of Entrepreneurship and Small Business, vol. 3, pp. 183-189, 2006.

[3] L. D. Ponthieu and R. G. Insley, "Rethinking the effects of small business failure," Journal of Business and Entrepreneurship, vol. 8, pp. $32-42,1996$.

[4] D. Smallbone, B. Piasecki, U. Venessar, K. Todrov, and L. Labrianidis, "Internationalization and SME development in Transition Economies: An International Comparison," Journal Small Business and Enterprise Development, vol. 5, pp. 363-375, 1999.

[5] D. Smallbone and U. Venessar, "The strengths and weaknesses of Estonian SMEs in context of an enlarged Europe. In managing Complesxity and change in SMEs," presented at the RENT XVIII, 2004. 
[6] C. M. V. Prag and P. H. Versoloot, "What is the value of Entrepreneurship? A review of recenet research," Small Business Economics, vol. 29, pp. 351-382, 2007.

[7] D. Valliere and R. Peterson, "Entrepreneurship and economic growth: Evidence from emerging and developed countries,' Entrepreneurship\& Regional Development, vol. 21, pp. 459-480, 2009.

[8] N. U. Haque, Entrepreneurship in Pakistan: Pakistan Institute of Development Economics, 2007:29.

[9] W. Bank, "Bringing Finance to Pakistan's Poor; Access to Finance for small Enterprises and the Undeserved," World Bank 2009

[10] F. Allan C and R. W. Pricer, Growing Companies: Tools for small business Success: Madison: Magna Publications, Inc., 1991.

[11] W. P. Sineath and W. E. Howie, "Small business concepts and their relationship to performance. A field study of retail service stations," Journal of Small Business Management, vol. 25, pp. 55-64, 1987.

[12] B. W. Keats and J. S. Bracker, "Toward a theory of small firm performance: A conceptual model," American Journal of Small Business, vol. 2, pp. 42-58, 1988.

[13] Z. M., "Off the beaten path: What must new age entrepreneurs do to succeed," Managemenr Review, vol. 83, pp. 28-31, 1994.

[14] D. Hussain and J. Windsperger, "Multi-Unit Ownership Strategy in Franchising: Development of an Integrative Model," Journal of Marketing Channels, vol. 17, no. 1, pp. 3-31, 2010.
[15] R. N. Lousier and S. Pfiefer, "A cross-national prediction model for business success," Journal of Small Business Management, vol. 39, pp. 228-239, 2001

[16] I. M. Kirzner, How Markets Work: Disequilibrium, Entrepreneurship and Discovery: The Institute of Economic Affairs: London, 1997.

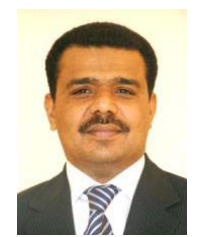

Manzoor Ali Mirani is Assistant Professor in Department of Business Administration, Sukkur Institute of Business Administration, Pakistan. Mr. Mirani holds Masters in Management Sciences. His areas of interest are Entrepreneurship, Small Business and Online Social Networking.

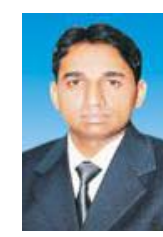

Syed Mir Muhammad Shah is Assistant Professor and Head of Department of Business Administration, Sukkur Institute of Business Administration, Pakistan. Mr. Shah holds Masters in Management Sciences from Pakistan. His areas of interest are Small Business and Accounting. 